\title{
Leadership at Godrej: a treasured heirloom transformed into a valuable brand
}

\author{
Lopamudra Pattanayak, Lalatendu Kesari Jena and Kalpana Sahoo \\ Xavier School of Human Resource Management, \\ Xavier University Bhubaneswar, Bhubaneswar, India
}

Received 28 June 2020

Revised 10 August 2020 29 August 2020

Accepted 29 August 2020

\begin{abstract}
Purpose - The purpose of this study is to bring out the success of the Godrej Group, focusing on their leadership styles and discussing how authentic and ethical leadership leads to value-based leadership (VBL), which has its eminence in the post-COVID-19 world.

Design/methodology/approach - The case study has been designed based on secondary published sources and few informal interactions with the leaders associated with the Godrej Group.

Findings - It was found that VBL is derived from authentic and ethical leadership and Adi Godrej, Chairman of Godrej Group, managed to sail through all these years successfully by adopting the authentic, ethical and VBL style, thereby transforming the family business into a global business and a valuable brand.

Originality/value - The case study is based on secondary published sources and informal interactions with the Godrejites. The different elements and eminence of authentic, ethical and VBL styles are explored. These values will play a significant role in the post-COVID-19 world. Value-based leader inculcates a clear, honest, empathetic and simple approach to employer-employee communication as the COVID-19 situation evolves. This case will therefore be of value to anyone using or considering a value-based approach to developing a successful leadership culture. These include Masters of Business Administration students, entrepreneurs, professional practitioners, etc.
\end{abstract}

Keywords Values, Workers, Authentic leadership, Ethical leadership, Family business, Value-based leadership, Employees, Volatile, Uncertain, Complex, Ambiguous

Paper type Case study

\section{Introduction}

Our values and the determination to stick to the values are set down the various layers of our management very strongly because in the long run, it pays - Adi Godrej

These were the words ringing on each student's ears on the Institute Foundation Day Lecture, 2018 at Xavier Institute of Management, Bhubaneswar (XIMB) on December 5, 2018 [1]. Shri Adi Godrej, Chairman, Godrej Group, was invited to the institute and the students had the privilege to interact with the Padma Bhushan awardee in person. He was conferred with Honorary Doctorate in Management by the institute on that day. His address to the students regarding his company and the various business models used were

(C) Lopamudra Pattanayak, Lalatendu Kesari Jena and Kalpana Sahoo. Published in Vilakshan - XIMB Journal of Management. Published by Emerald Publishing Limited. This article is published under the Creative Commons Attribution (CC BY 4.0) licence. Anyone may reproduce, distribute, translate and create derivative works of this article (for both commercial and non-commercial purposes), subject to full attribution to the original publication and authors. The full terms of this licence maybe seen at http://creativecommons.org/licences/by/4.0/legalcode

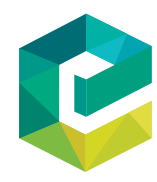

Vilakshan - XIMB Journal of Management Vol. 17 No. $1 / 2,2020$ Emerald Publishing Limited e-ISSN: 2633-9439 p-ISSN: 0973-195 DOI $10.1108 / \mathrm{XJM}$-06-2020-0013 
$\mathrm{XJM}$

$17,1 / 2$

intriguing and fascinating for all the budding managers and entrepreneurs in the auditorium. He even cited his association with the Xavier fraternity wherein he studied in St Xavier's School and College in Mumbai before he began pursuing his education abroad. The Indian economy has been significantly influenced by family business which contributes $70 \%$ to the GDP. There has always been a challenge and opportunity for a family business to survive and succeed in the competitive world across different generations. Succession planning, sibling rivalry, joining of less woman in the family business, biased decisionmaking and internal family conflicts are the major issues of any family business (Kavediya, 2017). However, a leader's values are the identity which motivates the followers under one roof. Followers consider this leader's role as a protector, promoter and a role model. The legacy of the "Godrej" brand had been sanguine in everyone's minds throughout their upbringing. It has triumphantly established itself as a valuable brand, rather than just being a family business which has survived and flourished over generations after its inception. It is a dream company for several B-school students, wherein management students strongly aspire to becoming a part of the company at some point in their careers. Success of any organization lies in the strength of its leaders and Adi Godrej set the pace of achieving success in every feat of his tenure in the company. Not only the students, Adi Godrej's lecture demonstration was treasured by all the faculty members, board members, press and other dignitaries present on the Foundation Day of the institute. The ex-Vice Chancellor of XIMB, Professor Dr Fr. Paul Fernandes, S.J., proclaimed how Adi Godrej's life has been an inspiration for many. He said that Adi Godrej's simplicity helped in building up the family business into a global business today. As per Fr. Paul, such an intriguing business model is a subject for several case studies for budding business tycoons. The inspiration to write this case study has thus, been derived from the Foundation Day Lecture, 2018 in XIMB. This case study focuses on the leadership styles, emphasizing on authentic and ethical leadership, transforming into value-based leadership (VBL), which helped Adi Godrej to triumph his family business.

The relevance of the case study also emphasizes on the post-COVID-19 world. With holacracy governance coming into workplaces and people resorting to remote workplaces and working from homes during COVID-19, workplace practices have seen a tumultuous change. With no vaccines available till now for COVID-19, empathetic employers are needed. At times when volatility, uncertainty, complexity and ambiguity are rising, employees today watch out for a leader with whom they can connect more. Value-based approach provides that connection. Without physical presence at offices and workplace areas, it is this VBL which gives the "real" experience to employees via virtual means. At such times, VBL not only helps to build the company, but also helps to make the communities at large more resilient and adaptive.

\section{Godrej Group: the genesis}

The Godrej Group follows a family business model. The Godrej family holds the majority holdings (ranging from 50 to 100\%) in most of its corporations. The role of the family members have been more of a trusteeship in growing the business and therefore the group has never experienced a single split, in its 123-year old history. The group's senior management consists largely of the family members only. In the present day, the fourth generation has just commenced entry into the business (Figure 1). The youngest generation of the family is made to join at the lowest executive levels like other executives. There is a strong and a systematic succession planning wherein these executives are groomed and trained under the guidance of the senior family members and outside professionals. When found credible and deserving, they climb up the corporate hierarchy. Godrej's inception 


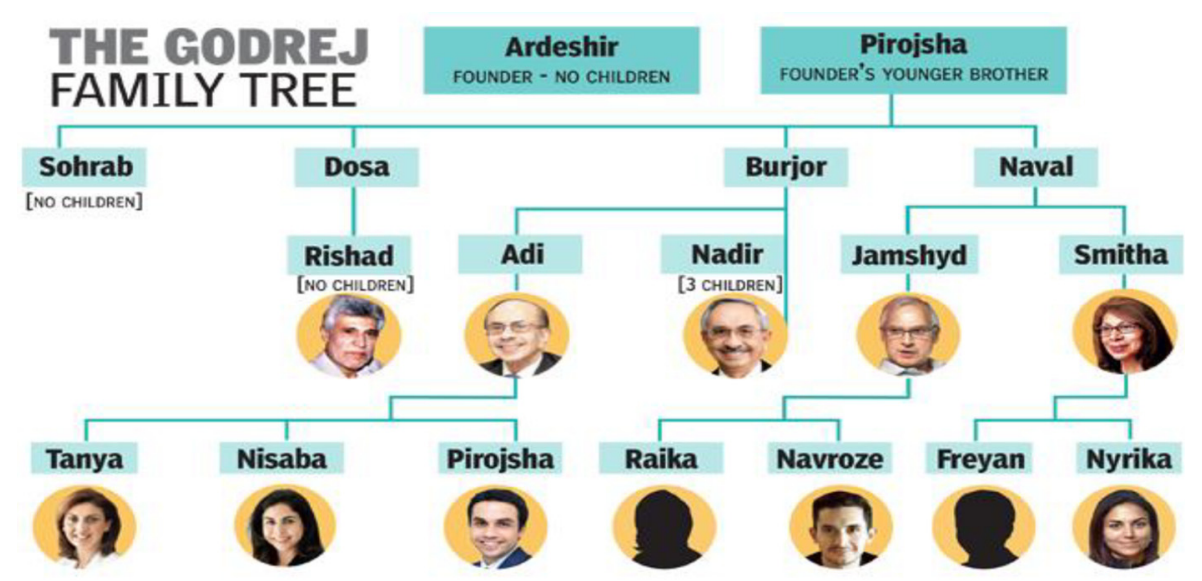

Leadership at Godrej

Source: https://timesofindia.indiatimes.com/business/india-business/godrej-fourth-genlooks-to-chart-separate-paths/articleshow/69966101.cms (accessed June 25, 2020)

Figure 1. Godrej family tree

dates back to 1897, which was an era of India's Swadeshi Movement i.e. the original "Make in India" movement [2].

As the famous French saying goes, "Rome wasn't built in a day, but they were laying bricks every hour." Thus, many years of diligent work and persistence are the reason behind which the absolute greatest organizations have prospered over time. The Godrej Group is part of one such success story. Ardeshir Godrej was the most established of six youngsters in a Parsi-Zoroastrian family who was born in Bombay in 1868. His father Burjorji Gootherajee changed their family name to Godrej when Ardeshir was three years old. Ardeshir pursued law, similar to the standards and practices of other Indian wealthy families, during the British Raj. Soon after his graduation, Ardeshir was given a short spell by a firm called Bombay Solicitors in 1894 (Church, 2015). He got his first relegation which expected him to visit Zanzibar to battle a case for their customer. The case was working out as expected when Ardeshir discovered that he would need to control the certainties of the case so as to exhibit his customer's guard or at the end of the day he would have to lie. A man of standards, he declined to proceed with the case and no influence by the customer or other specialists could persuade him to change his firm position. He returned to India with a heavy heart as he realized his law profession had sunk even before it had begun cruising. However, he continued his short-lived law profession with a vocation in a scientific expert shop and there he was intrigued by the assembling of careful instruments. This led him to begin his first business of surgical instruments, which did not progress either. Despite such failures, Ardeshir, being a true nationalist and an avid supporter of the Swadeshi Movement, was resolved to proceed with a manufacturing and assembling business in India. He got a credit and an incredible lift from Merwanji Cama, a prestigious Parsi representative and humanitarian, to begin a lock-production business. The rising burglaries in Mumbai at that time embarked the idea of starting this lock-manufacturing venture. This marked the beginning of the Godrej Group, as we know today, in the year 1897 (Dey, 2017). His lockmaking business was a hit, and he further expanded his business to manufacture safes. The Godrej prosperity under Ardeshir was immense. His entrepreneurial spirit and a solid vision enabled him to start building the pillar of the Godrej Group. 
$\mathrm{XJM}$

$17,1 / 2$

Ardeshir was joined by his younger brother Pirojsha Burjorji Godrej in his business in the year 1906 at a young age of 24. He did his graduation from Victoria Jubilee Technical Institute, Mumbai. Both the brothers came to be known as the Godrej Brothers who shaped Godrej Soaps Ltd in 1918. They propelled the world's first cleanser made without using creature fat, which was launched as Chavi. Later, the soap was popularized as Cinthol in 1952. It had been Pirojsha's vision to assist the family business to grow and diversify into new products. He was a strategic leader. He set a clear direction for the organization, aligning individuals' direction through communication, and thus motivating these individuals to action. He prioritized both, the organization's production desires and the people's desires. He did this by ensuring that his team members understood the organization's purpose, and by involving them in deciding production desires. Once both the desires coincided, it created an environment of trust and respect, which ended up in high satisfaction, motivation and wonderful results. After locks and soap, they forayed into furniture business with manufacturing almirahs i.e. steel cupboards in 1923. In 1928, Ardeshir transferred the possession and management of their family business to Pirojsha completely. In 1943, the then Government of Bombay auctioned Vikhroli village to Pirojsha, who transformed the area into a green industrial township that cared for its people and the environment. They made a strong entry into the home appliances market with their first refrigerators in the year 1958 .

Pirojsha's son Sohrab Pirojsha Godrej was appointed the chairman of each of the businesses Godrej and Boyce and Godrej Soaps in 1972 following his father's demise. Sohrab was a pacesetter who was cautious of the political mirage that existed in Indian landscape. At his time, Indian businesses were attempting to garner a world platform for their products. He was occupied in promoting Indian products as well as Godrej products at world forums and even established trade relations at a global level (Godrej and Karanjia, 2001). During his tenure in Godrej, he headed several international business forums such as the International Chamber of Commerce India, the Council of EU Chambers of Commerce in India, Indo-French Chamber of Commerce and Business, the Indo-Belgian Chamber of Commerce and Business and also the Indo-French Technical Association. This commanded love and respect within the eyes of Indian businessperson for Sohrab and his ideologies were widely accepted and approved of. He was able to effectively unify the Indian businesses in the times of uncertainty. He possessed the qualities of emotional intelligence. He garnered his workers' adulation by involving himself in their personal concerns, issues, living conditions, etc. He had the precious quality of bestowing trust on his workers and employees who always supported his decisions.

\section{Adi Godrej's notable emergence}

Over the years, the Godrej Group has ventured into several business fronts. Apart from the businesses mentioned above, Godrej forayed into hair dye products, properties and real estate, agri-business, mosquito repellents, gourmet retail, air care and building aerospace engines. Their business spread across nations. The determined leaders of the Godrej Group toiled and created this valuable brand. One of the most eminent personas in this benefaction is Shri Adi Godrej, the current Chairman of the Godrej Group. He is Sohrab Godrej's nephew and Burjor Godrej's son, who joined the family business in the year 1963 after finishing his education from Massachusetts Institute of Technology (MIT) Sloan School of Management in USA [3]. Adi Godrej pursued his bachelors and masters majoring in management and took up mechanical engineering as his minor in MIT, thus adding several feathers to his cap. He was the first management graduate in the Godrej clan and thus the senior management of the Godrej Group had high expectations from him when he returned to India. He is 
considered to be one of the richest Indians with a net worth of US\$2.2bn and is a well-known icon in the Indian business history [4].

Adi took advantage of his knowledge on management studies, his exposure through early travels and his attitude of adaptability in every situation. He tried to implement whatever he garnered during his education practically in his family business. According to him, his tenure in America, a stint at MIT has stayed with him and it has greatly influenced his business. As member of Pi Lambda Phi - a fraternity at MIT, which was known for welcoming people of all races and religions, he learned the importance of building teams and retaining people. The Godrej Group worked in an inflexible style of management which was followed in the era of British rule, even after India's independence. Hence, on Adi Godrej's arrival in the company, he faced the challenge of modernizing the management structures and making them more flexible and systematic. His attempts toward process improvements led to the progress and growth of the Godrej Group. Adi initiated the group's movement away from family hegemony that inflicted many family businesses of that time in India. He ensured this by appointing chief executive officers (CEOs) from outside the Godrej family to head the various group companies. He started recruiting from the renowned management schools such as Indian Institutes of Management in India, which were still in their nascent stage in key positions for his company at that time [5]. He inculcated new business processes at a time when companies perceived "change" to be disruptive and threatening. He built an emotional connect of both his personal and the group's brand image with people by maintaining traditional middle-class core values.

Adi is inspired by the ancient Greek philosophers Socrates, Plato and Aristotle. He was greatly influenced by the mentor-mentee culture followed during that era. Apart from this, he was also influenced by leaders such as Nelson Mandela and Margaret Thatcher who transformed the country and society and took them to greater heights. He had always been tech-savvy and took special interest in technology adoption which benefited his business. He understood that innovation is the key to stay at par with the cut-throat competition in the market. Remaining continuously at the cutting edge, understanding the consumers extremely well and letting consumers dictate the company policies are essential. He believes that having 750 million consumers in India and 1.1 billion consumers globally, in itself emphasize the importance of consumer say. Under his leadership, the Godrej Group kept overhauling growth targets and reached great heights of success [6]. The growth trajectory can be very well understood by its turnover value over years and other financial statistics (Figures 2 and 3). With his efforts, Godrej transformed into a conglomerate from a kick start with locks to selling personal care, and then even homes to Indians. Under his stewardship, Godrej Consumer Products has emerged into a strong market fast-moving consumer goods (FMCG) player based on a $3 \times 3$ approach to international expansion, building a presence in three emerging markets (Asia, Africa and Latin America) across three categories (home care, personal wash and hair care). The two important mantras responsible for his success are first, the need to imbibe and follow best practices in the organization and second, to know the trade and know it well. He also emphasizes on team work and collaboration being the base to reach the zenith.

As per Adi, using the word "we" fosters strength in individuals always. Adi's younger brother Nadir Godrej and first cousin Jamshyd Godrej had also been illustrious businessmen alongside Adi. Today, when the fourth generation of the Godrej clan i.e. Adi's, Nadir's and Jamshyd's children have begun taking up key positions in their family business, several conflicts have erupted. The conflicts within the Godrej family over business strategy are presumably a clash of the young lot's personalities. These Millennials are fast movers and there is bound to be friction among them, because of varied ideas, paths and choices. It is 
Figure 2.

Turnover of Godrej Consumer Products between FY 2015 and FY 2019

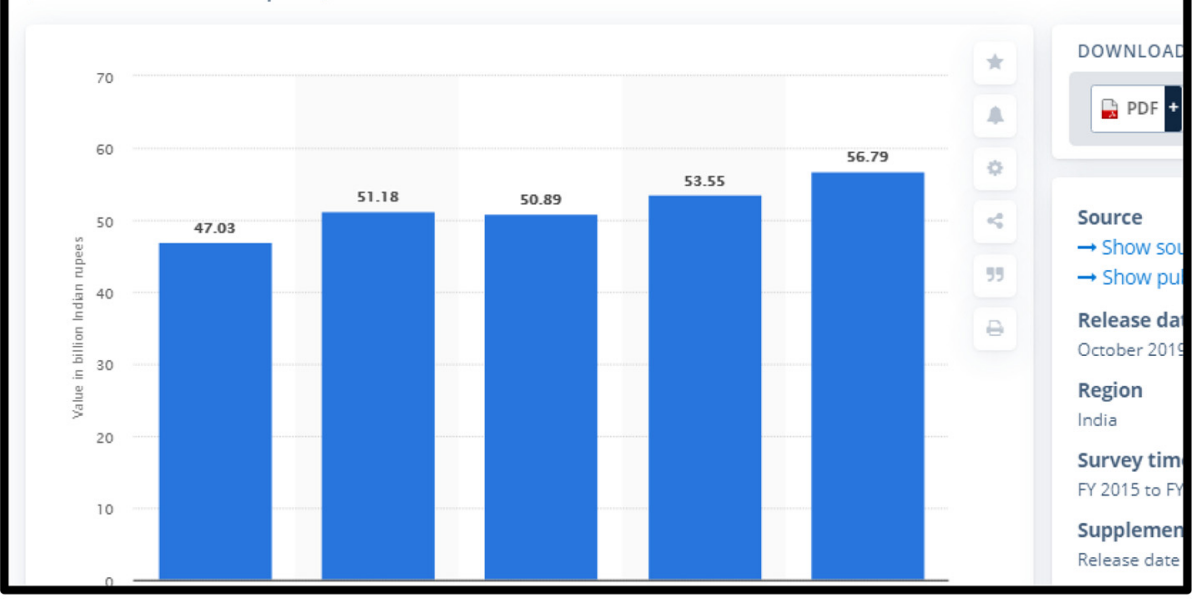

Source: www.statista.com/statistics/1065544/india-godrej-consumer-products-turnover/ (accessed August 9, 2020)

evident that the real estate business is the primary cause of differences. The difference of opinion came up between Adi Godrej and Nadir Godrej on one side and their cousin Jamshyd Godrej on the other side. Despite differences, Adi Godrej, being the man of values as he is, tried to resolve the issues in a sophisticated way rather than washing dirty linen in the public, with the help of external advisors. The resolve is still under way, as unlike a corporate set-up, family businesses have a closer ownership and each family member has an emotional involvement in it. Such a prolific businessman, Adi is still creating history in one of the fastest growing economies of the world, India. He has been a recipient for several awards in several categories over the years for his impeccable leadership and business acumen. He is an industrialist, but a philanthropist by heart. He is value-driven and is famous for his simplicity, punctuality and focus.

\section{Influence of Adi's leadership on Godrej}

Adi Godrej is the most successful leader in the Godrej family business. As per Adi, leadership is about doing the tough things which need to be done and no one else wants to do, not just the popular ones. It is about telling the truth about how things are, not what people want to hear (Chopra, 2014). Under his leadership, Godrej grew into a conglomerate. His focus was not to drastically change everything in Godrej to begin with. He just wanted to add competitive value. Godrej completed the 10 years of restructuring process in 2001 under the visionary leadership of Adi Godrej. With reasons such as economic reforms for rapid growth, Adi concentrated toward the lower end of the society. This included focused approach toward inclusive growth which would provide equal opportunities for all. Adi is responsible for creating the focus on value creation which led to the process improvements in the company. From the era of liberalization in India, Adi Godrej made sure to encourage innovation in all the different businesses owned by him. Innovation has always been the 


\begin{tabular}{|c|c|c|c|c|c|}
\hline & \multicolumn{5}{|c|}{ Fs (in Crenes) } \\
\hline & Mar'20 & Mar'18 & Mar'18 & Mar'17 & Mar'16 \\
\hline \multicolumn{6}{|l|}{ INCOME } \\
\hline Net 8sues Tumover & 1968.72 & 2143.99 & 1958.33 & 1500.09 & 1302.95 \\
\hline Other Income & 60.93 & 41.79 & 33.43 & 46.88 & 25.47 \\
\hline Total Insoma & 2028.86 & 2186.78 & 1881.78 & 1648.87 & 1328.42 \\
\hline \multicolumn{6}{|l|}{ EXPENaEs } \\
\hline Etodk Ad] ustments & 6.95 & 7.65 & 13.29 & -45.05 & -5.66 \\
\hline Fusw Maserial Cansumed & 1187.66 & 1289.35 & 1278.94 & 1111.86 & 829.00 \\
\hline Power and Fuel & . & o & .00 & oo & .00 \\
\hline Employee Expenses & 145.74 & 130.17 & 133.55 & 116.25 & 135.05 \\
\hline Administratian and Belling Expenses: & .00 & .00 & .00 & .00 & .00 \\
\hline Research and Develiapment Expenses: & .00 & .00 & .00 & .00 & .00 \\
\hline Expenses Capitsilsed & .00 & .00 & .00 & .00 & .00 \\
\hline Other Exoenses & 335.28 & 311.73 & 295.70 & 249.97 & $25+.37$ \\
\hline Pravisians Mose & .00 & .00 & .00 & .00 & .00 \\
\hline TOTAL EXPEN 8E \& & 1876.78 & 1788.80 & 1721.48 & 1482.08 & 1208.78 \\
\hline Operating Proft & 292.99 & 405.09 & 236.85 & 68.06 & 93.19 \\
\hline EBITOA & 368.82 & 448.88 & 270.28 & 114.84 & 118.88 \\
\hline Depresiatian & 68.62 & 54.30 & 68.58 & 52.43 & 44.37 \\
\hline EEIT & 286.80 & 382.68 & 201.70 & 62.61 & 74.28 \\
\hline Interest & 228.99 & 239.59 & 212.43 & 207.86 & 200.24 \\
\hline EET & 68.21 & 162.88 & -10.78 & -146.86 & -126.86 \\
\hline Taxes & -.12 & -.07 & 15.25 & $=-11$ & -25.95 \\
\hline Profit and Loes for the Yoar & 68.48 & 168.08 & -25.88 & -146.24 & -100.00 \\
\hline Extraordinary ltems & -25.62 & -243.79 & 267.38 & .00 & 134.21 \\
\hline Prior Year.Ad!ustment & .00 & .00 & .00 & .00 & .00 \\
\hline Other Adlustment & oם. & .00 & .00 & .00 & . \\
\hline Reportad PAT & 80.81 & -80.75 & 241.40 & -146.24 & 84.21 \\
\hline
\end{tabular}

Source: https://economictimes.indiatimes.com/godrej-industries-ltd/yearly/companyid-11764. cms (accessed August 9, 2020)
Leadership at Godrej

Figure 3.

Financial results of Godrej Industries Ltd over years 
$\mathrm{XJM}$

$17,1 / 2$

crux of Godrej's business model. The Zoroastrian virtues of uprightness, charity, generosity and benevolence have been instilled in him firmly. Be it success or failure, his values and virtues were undeterred. His leadership styles portray his value-driven personality. According to him, he has adopted different leadership styles over time. It had been a learning experience for him too.

- Delegative leadership style: Earlier Adi was more authoritative but with time he shifted toward being a delegative leader. He worked on his listening skills and involved his team mates to take decisions. He realized the need for different CEOs in the different group companies and delegated the decision-taking responsibilities to his workers.

- Transformational leadership style: Transformational leader encourages, inspires employees to innovate and creates change that will bring transformation in the organization. Adi Godrej is a man of wisdom. An effective listener and an empathetic leader, he was successful in developing an emotional connection with his workers and employees. He believes in the motto of thinking future backwards wherein he works with his teams to identify needed change via different perspectives. His wisdom and knowledge has always enabled him to have a clear vision and guide his subordinates in an inspirational way. The tale behind investment of Sara Lee's in Godrej's consumer products business tells us about Adi Godrej's quick decision-making and foresight. In 1994, Transelektra Domestic Products, an insecticide manufacturing company was up for sale. The company had sold insect repellents under Hit brand and mosquito repellents under Good Knight brand. Hindustan Unilever was very interested in acquiring Transelektra but was struggling to get permission from its global parent company. Godrej quickly sensed this opportunity and conducted a swift due diligence of the organization along with its sector of operation. Finally Godrej could acquire the company for Rs. 80 crore and for eliminating the risks to a new business, Godrej got Sara Lee on board and sold half of the acquired company to the US firm at the price that Godrej had to pay for entire Transelektra. In conclusion, Godrej got $50 \%$ of the stake in company for free of cost which was done under the leadership of Adi Godrej.

- Authentic leadership style: As mentioned earlier, Adi had deep emotional connect with his workers and employees. His imbibed Zoroastrian values and virtues helped him to build integrity as an important characteristic in him. His honest relationships with his workers and employees promoted openness, trust and commanded respect from all. His philanthropic nature garnered praises and immense followers even outside his family business. He emphasized more on people and ethics, rather than just the bottomline. Authenticity refers to the whole integrity of the self and a basic attitude of sincerity (Dion, 2012). Authentic leaders have four basic characteristics, i.e. self-awareness, transparency, balanced processing and a moral perspective. These are the key pillars of value-based leader. Authenticity is basically a precondition for ethical leadership (Trnka et al., 2019).

- Ethical leadership style: Along with the exemplary contribution of Adi Godrej toward the success of Godrej, he contributed immensely toward building an ethical culture in the company. His path breaking contributions as a dedicated leader has set many great examples for the emerging leaders of India. As an ethical leader, he has worked and succeeded transforming societal and business scenario of the country. Adi Godrej got the Golden Peacock Lifetime Achievement Award in 2017 for the above-mentioned reasons [7]. The significant benefits of ethical leadership 
cascade down from top management levels to employee levels (Mayer et al., 2009). It emphasizes moral awareness among organizational members. Thus, as discussed above, every ethical leader is always an authentic leader, but the vice versa may not be true always.

- Value-based leadership style: The major three dimensions of a value-based leader are leading self, leading others and leading the organization (Frost, 2014). An amalgamation of ethical and authentic leadership styles leads to VBL. Adi Godrej's leadership reflects the strong Parsi ethos engraved in him. He lives by the moral code derived from the Zoroastrian motto, "Good thoughts, good words and good deeds" [8]. The authentic and the ethical persona of Adi helped him to remain humble and grounded, which is a principle on which VBL is based upon (Zydziunaite, 2018). The Godrej Group's core values i.e. integrity, trust and respect for others are a sole reflection of their leader, which are integral across all their operations, functions and business activities. The four principles of values-based leadership are self-reflection, balance, self-confidence and humility (Kraemer, 2011). Adi Godrej is the true representation of all these qualities. The Vision-2020 of the Godrej Group includes creating a shared value through Good and Green. The brand value created through organic and inorganic growth has led to improvements in social and relationship capital. This has strengthened the financial capital and has diversified their human capital [9]. In the wake of the global pandemic COVID-19, VBL has garnered prominence, which can very well be seen in Adi Godrej as well.

The impact of value-driven leaders has been very much eminent during volatile, uncertain, complex and ambiguous business situations. As per the Economic Times Great Place to Work Survey, Godrej Consumer Products Limited has been recognized among India's Best Companies To Work For in 2019 and among India's Best Workplaces in Manufacturing in 2020. It holds the 21st rank and has successfully created a great place to work for all employees as they excelled in five dimensions of credibility, respect, fairness, pride and camaraderie. The culture snapshot talks about the family like environment of Godrej offered to all employees with many positive employee testimonials (GPTW, 2019). This could also be seen in Adi Godrej's stance during the COVID-19 pandemic in 2020.

\section{Adi Godrej's interventions in COVID-19 and the path ahead}

The COVID-19 outbreak has brought the world economy to its knees. The FMCG sector and the real estate have also been affected immensely. Because of the coronavirus outbreak, value growth of India's consumer goods makers fell to its lowest in at least seven quarters (Dsouza, 2020) (Figure 4). Availability of labor for the industry has posed a challenge in scaling up the industry amid the coronavirus outbreak. Movement of migrant laborers back to their hometowns across the country has been a matter of concern for several businesses. There has been a continuing slowdown in the economy, yet the Godrej Group is surviving fairly well under Adi's leadership. By and large the Godrej Group had achieved their targets in the fiscal year 2019-2020. Adi Godrej believes that goods and services tax has been a good reform in the Indian economy, and it will be good even in the long run. However, the people's purchasing power has come down because of the pandemic and the subsequent lockdown worldwide, which has negatively affected the buying propensity of consumers. Despite such a slack in business, Adi Godrej had been pretty optimistic about the whole situation. Godrej's business depends a lot on the agricultural sector. The upcoming monsoon-related issues have also not deterred Adi's optimism. According to Adi, good rabi crops are expected in the monsoon and that would be a turnaround for the agri-sector, 


\section{2}

Figure 4.

Year-on-year value growth of FMCG sector in calendar year $(\%)$

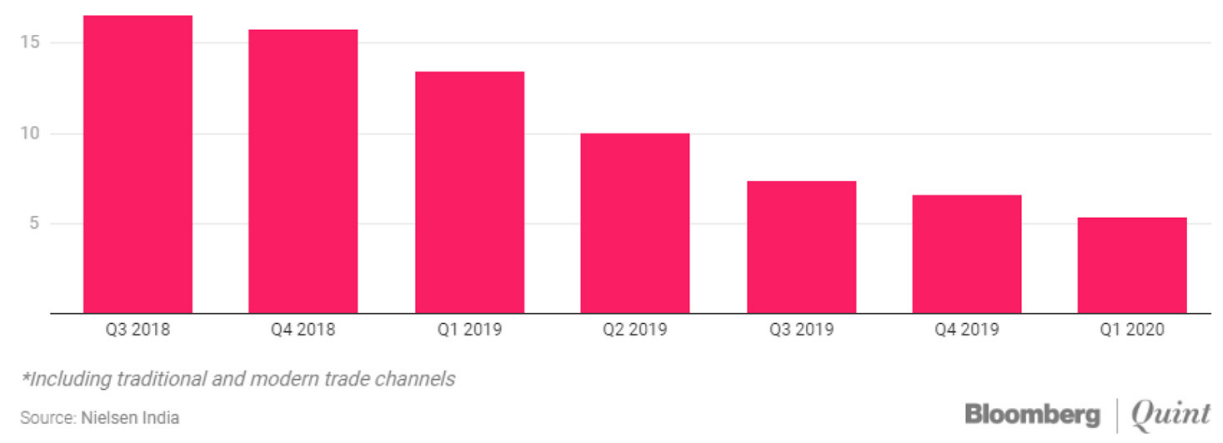

Source: www.bloombergquint.com/business/covid-19-stalls-fmcg-sectors-nascent-recoverysays-nielsen-india (accessed June 26, 2020)

channeling down the effect on the Godrej Group. In fact, Adi Godrej believes that coronavirus outbreak could prove to be an opportunity in certain cases for India because China would be unable to supply some of the products, which could be easily taken up by India [10].

In these testing times, Adi Godrej yet again showed his VBL characteristics. The Godrej Group earmarked Rs. 50 crore to fight COVID-19. It has launched a slew of initiatives for support and relief. It has leveraged capabilities by exploring its medical refrigerators business as well as construction capabilities to build quarantine rooms to use its vast expertise in mechanical, electrical and plumbing systems for hospitals. The company worked for providing medical equipment and protective supplies in Maharashtra, which is the worst-affected state because of COVID-19 in India. It donated Rs. 5 crore to the Brihanmumbai Municipal Corporation for buying and supply of medical equipment and protective gears. It donated 115 hospital beds to Maharashtra Government hospitals for treating COVID-19 patients. Being the second-largest soap-maker in India, the Godrej Group launched \#ProtektIndiaMovement, which is a nationwide, multi-media and multi-channel campaign to promote mass awareness about hand-washing and public health. As a part of this initiative, it distributed one million packets of Godrej Protekt Mr. Magic powder-toliquid hand wash across Maharashtra for free. The company has also been supporting 1.12 lakh beneficiaries across eight states of the country with hand wash, sanitizers and soap and has partnered with communities linked to its corporate social responsibility programs. Several hand-sanitizers have been donated to the Mumbai police force as well. The company has also begun ramping up capacity to meet the demand for soap, hand wash and sanitizers in India [11].

The Godrej Group has provided support not only to the society, but also to their workers and employees during this pandemic situation. It has committed support to its contract laborers and workers at factories and construction project sites. As one of India's largest real estate players, it is concerned about the problems being faced by migrant laborers [12]. For this, Godrej has initiated the following steps:

- Ensured that its project sites across its eight cities are being sanitized at frequent intervals, and they have health screenings and adequate food and hygiene supplies at all times for all their employees. 
- Set up isolation facilities at its labor accommodation areas and is closely monitoring the needs of the workers throughout.

- Will continue to build on these efforts with safety, compassion, ideas and hard work so that everybody can come out stronger and full of positivity on the other side.

Several times, during Adi Godrej's career, Godrej faced a lot of criticism when compared to other old Indian business houses such as Tata, Birla and Ambani saying that it has not grown fast enough. Adi Godrej acknowledged that his business has not grown as big as its old rivals, pointing out that Godrej grew comparatively slower because of his desire to keep out of tightly regulated businesses. Godrej group started following the "bottom-of-thepyramid" strategy to other low- and middle-income countries in Africa, Latin America and Asia. The results were slow yet promising. Thus, Adi Godrej's innate core intelligence has helped him sail through effectively all these years. Despite the ascent of the new generation, the fulcrum of the Godrej Group's operations i.e. shared leadership with professionals remains intact. Godrej's success in withstanding the volatilities, uncertainties, complexities and ambiguities of the marketplace in recent years is attributed to the successful collaboration of family members with outsiders. So far, the Godrej children have excelled in their roles. The values instilled in them during their upbringing, has demonstrated characteristics of VBL in their professional stint. In a bold move and a significant leadership change, Adi Godrej's daughter, Nisaba Godrej will take over the role of Managing Director and CEO, Godrej Consumer Products in July 2020. Now comes the harder part. For instance, they have to fill the big shoes of Adi Godrej. They also have to steer the group through a challenging macroeconomic environment. The promoter of a leading family owned business says that the family members need to have a fair degree of accommodation and influential skills with the maturity needed to lead an organization with non-family professionals. If the Godrej family succeeds at that, they will not be on the ropes and will reach the top. The fourth generation of Godrej will also have to identify new businesses to ride the next wave of growth. Godrej Group will have to be more aggressive to stay ahead in the competitive market. Hence, by inculcating and balancing values, interests and power among citizens, workers, employees and leaders, the next-gen of Godrej legacy will strive harder and soar higher.

\section{Notes}

1. www.youtube.com/watch?v=j5n3Vp0or_M

2. www.godrej.com/our-story.html

3. https://en.wikipedia.org/wiki/Adi_Godrej

4. www.forbes.com/profile/adi-godrej/\#668e30d17867

5. www.youtube.com/watch?v=SnSN_uSFrRQ

6. https://business.mapsofindia.com/business-leaders/adi-godrej.html\#: :text=Adi\%20Godrej $\% 20$ was $\% 20$ born $\% 20$ on,which $\% 20$ includes $\% 20$ many $\% 20$ Indian $\% 20$ companies.\&text=In $\% 202010$ $\% 2 \mathrm{C} \% 20$ Forbes $\% 20$ estimated $\% 20$ his,the $\% 20$ richest $\% 20$ persons $\% 20$ in $\% 20$ India

7. https:/goldenpeacockaward.com/leadershipawards/leadershipwinner18.html

8. https://shodhganga.inflibnet.ac.in/bitstream/10603/7881/6/06_chapter\%202.pdf

9. https://godrejcp.com/public/uploads/reports/2018-19/10_Our_Strategic_Pillars_201819.pdf 
$\mathrm{XJM}$

$17,1 / 2$

10. https:/economictimes.indiatimes.com/markets/stocks/news/i-expect-2021-to-be-much-better-overallthan-2019-20-adi-godrej/videoshow/74133175.cms

11. www.thehindubusinessline.com/companies/godrej-group-earmarks-50-crore-to-fight-covid-19/ article31178732.ece

12. www.indiatoday.in/impact-feature/story/godrej-group-extends-its-support-to-the-indian-governments-fight-against-covid-19-1660689-2020-03-28

\section{References}

Chopra, S. (2014), When I Was 25: The Leaders Look Back, Random House Publishers, Gurgaon, India.

Church, P. (2015), Profiles in Enterprise: Inspiring Stories of Indian Business Leaders, Lotus Collection/ Roli Books, New Delhi.

Dey, S. (2017), "This man laid the foundation of a Billion-Dollar Made-In-India business empire in colonial times", available at: www.thebetterindia.com/87070/ardeshir-godrej-founder-innovator/ (accessed 25 June 2020).

Dion, M. (2012), “Are ethical theories relevant for ethical leadership?”, Leadership and Organization Development Journal, Vol. 33 No. 1, pp. 4-24.

Dsouza, S. (2020), “Covid-19 stalls FMCG sector's nascent recovery, says Nielsen India”, available at: www.bloombergquint.com/business/covid-19-stalls-fmcg-sectors-nascent-recovery-says-nielsenindia (accessed 26 June 2020).

Frost, J. (2014), "Values based leadership", Industrial and Commercial Training, Vol. 46 No. 3, pp. 124-129.

Godrej, S.P. and Karanjia, B.K. (2001), Abundant Living, Restless Striving: A Memoir, Viking, MI.

GPTW (2019), "India's best companies to work for 2019- A study by the economic times", available at: www.greatplacetowork.in/great/rated/100-best/Godrej-Consumer-Products-Limited (accessed 9 August 2020).

Kavediya, S. (2017), “Challenges and problems faced by family businesses in India”, International Journal of Science Technology and Management, Vol. 6 No. 4, pp. 30-34.

Kraemer, H.M.J. (2011), "The only true leadership is values-based leadership”, available at: www.forbes. com/2011/04/26/values-based-leadership.html\#4469baed652b (accessed 27 June 2020).

Mayer, D.M., Kuenzi, M., Greenbaum, R.L., Bardes, M. and Salvador, R. (2009), "How low does ethical leadership flow? Test of a trickle-down model”, Organizational Behavior and Human Decision Processes, Vol. 108 No. 1, pp. 1-13.

Trnka, R., Kuška, M., Tavel, P. and Kuběna, A.A. (2019), "Social work leaders' authenticity positively influences their dispositions toward ethical decision-making", European Journal of Social Work, Vol. 23 No. 5, pp. 1-17.

Zydziunaite, V. (2018), "Leadership values and values based leadership: what is the main focus?", Applied Research in Health and Social Sciences: Interface and Interaction, Vol. 15 No. 1, pp. 43-58, doi: 10.2478/arhss-2018-0005.

\section{Appendix 1}

\section{Teaching note}

Synopsis

The Godrej Group is one of the most established and broadened firms in India. From a lock-making organization in 1897 to a present-day conglomerate, the change has been incredible. It gives us a rich knowledge into an organization that effectively adjusted to a progressively evolving condition. 
Godrej is functioning in the spirit of Adi Godrej's purpose and passion, which promotes shared value to create inclusivity. His valuable experience and integrity in business are able to create trust among the customers, workers, employees and other stakeholders. Basically the case focuses on Adi Godrej's leadership capability to make Godrej as the most trusted brand and reaches to the lives of billions of people worldwide. He is the first management graduate of his family who brings a lot of changes in business, especially after the liberalization in 1991. It had been a challenging step for him to change the business family's direction and mindset. He confronted the challenge of modernizing the management structures and making them more flexible and systematic. He is inspired by the ancient Greek philosophers Socrates, Plato and Aristotle and the Zoroastrian-Parsi values and virtues of good thoughts, good words and good deeds, instilled in him since childhood. Apart from this, he was also influenced by leaders such as Nelson Mandela and Margaret Thatcher who transformed the country and society and took them to greater heights. Adi is a business tycoon by blood but a philanthropist by heart. He never discriminates between his family members and his employees. Adi Godrej utters "we" which shows his humbleness, honesty and respect for others. He develops a strong intimacy and an emotional connect with all the stakeholders, especially with the employees. He is a good listener who involves his teams in decision-making. He is not only committed to employees and customers, but he is highly concerned for the environment. The Godrej Group is highly concerned for pollution prevention, conservation of key resources such as water, fuel, energy, recycling and reuse of the waste materials and disposal of waste in an environment friendly manner.

Adi Godrej strongly believes that each generation has different skills and culture. Young or old, they will be able to harmoniously work with professionals across generations. The previous generations need to accept the involvement of new generation members. His main mantra is there is no substitute for hard work. A man of ethics, he has shown characteristics of an authentic leader and an ethical leader. This has helped him to embrace vale-based leadership which is the need of the hour to pass through volatile, uncertain, complex and ambiguous situations such as COVID-19. Adi Godrej's interventions during the pandemic situation are sanguine of his value-based leadership (VBL) style. Today the fourth generation of Godrej has taken up the charge of running their family business. These newbies will also have to identify new businesses to ride the next wave of growth. Godrej Group will have to be more aggressive to stay ahead in the competitive market. Hence, by inculcating and balancing values, interests and power among citizens, workers, employees and leaders, the next gen of Godrej legacy will strive harder and soar higher.

\section{Target audience}

The case study is relevant for both graduate and the post-graduate level students of management education. Apart from the management students, it is very much apt for budding entrepreneurs and also corporate professional practitioners, who are the first prey to volatile, uncertain, complex and ambiguous business situations. While the intention of this teaching note is geared more toward the leadership characteristics, the students could easily adopt this case study for use in their classrooms by replacing the additional readings with their own textbook chapter readings. The business school students are the future managers and leaders of the organizations, and understanding VBL style is inevitable.

\section{Teaching objectives}

The case study helps to analyze and understand:

- Adi Godrej's leadership characteristics which helped him to build up the family business.

- How authentic and ethical leadership style leads to VBL. 
$\mathrm{XJM}$

$17,1 / 2$
- The importance of VBL and its prominence in volatile, uncertain, complex and ambiguous business situations, such as the ongoing business impact because of COVID-19.

\section{Analysis of teaching objectives}

Leadership has a long past, but a very short history. The term leadership is usually used in common parlance. The term dates back to the times when Columbus began his voyage with a leaky boat. While a lot of thoughts and opinions surfaced, the concept of leadership did not attain any scientific status. The scientific research began during the war periods. However, there was an intellectual climate all over the world. There were Gandhi in India, Churchill in the UK, Roosevelt in the US, Hitler in Germany, Mussolini in Italy and General Franco in Spain. Because of this hero-worship climate, people started believing that leaders are born, not made. This gave rise to scientific research and interventions of leadership. In this case study, the focus is given on one such great business leader who led and transformed his family business during the era of Indian liberalization. It talks about the leadership characteristics of Adi Godrej, Chairman, Godrej Group. Major emphasis has been given on the VBL of Adi Godrej, which is derived from authentic and ethical leadership styles. The idea of embracing VBL during volatile, uncertain, complex and ambiguous business situations such as COVID-19 has been discussed.

Leadership framework

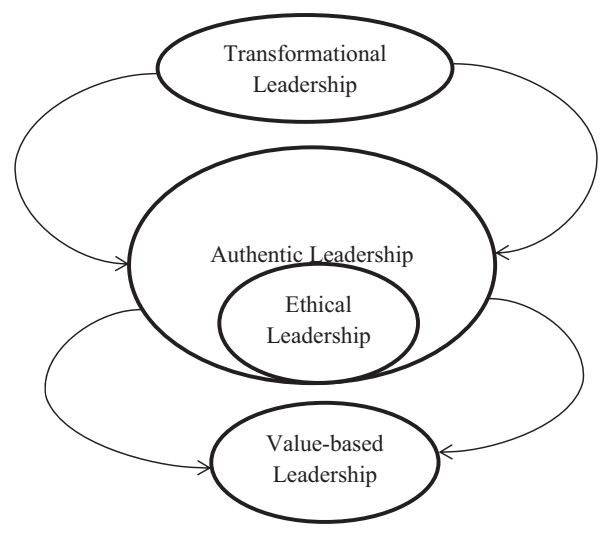

Source: Author's framework

\section{Teaching plan}

The Teaching Note follows a sequential order of presenting the case as suggested in the Teaching Plan (Appendix 2).

Case analysis

Few pertinent case related questions:

- What are the core constructs of a value-based leader?

VBL emerged as a bi-product of the time, culture and context. VBL identifies authentic, ethical and transformational leadership as its three core constructs. Authenticity refers to integrity of the self and a basic attitude of sincerity. Authentic leaders have four basic characteristics, self-awareness, 
relational transparency, balanced processing and internalized moral perspective, which are the key pillars of value-based leader. The significant benefits of ethical leadership cascade down from top management levels to employee levels. Ethical leadership emphasizes moral awareness among organizational members. Transformational leaders encourage, inspire employees to innovate and create change that will bring transformation in the organization.

- Adi Godrej is considered as the value based leader. Justify the statement.

Adi Godrej's leadership reflects the strong Parsi ethos engraved in him. He lives by the moral code derived from the Zoroastrian motto, "Good thoughts, good words and good deeds." The authentic and the ethical persona of Adi helped him to remain humble and grounded, which is a principle on which VBL is based upon. The Godrej Group's core values i.e. integrity, trust and respect for others are a sole reflection of their leader, which are integral across all their operations, functions and business activities. The four principles of VBL are distinguished by Jansen Kraemer (2011), which holds true for Adi Godrej.

- Self-reflection: Adi Godrej had the ability to reflect on his values and strengths. For taking any decision, he did self-reflection and strived for greater self-awareness.

- Balance: Adi Godrej perceived the situations from multiple perspectives and looked for more suggestions to gain a much fuller understanding. He was flexible and open-minded.

- Self-confidence: The leader recognizes his personal strengths and learning aptitude for continuous improvement. With true self-confidence, the leader can take the risk and challenge.

- Humility: A true, humble and simple person as Adi Godrej was able to build trust and commitment among employees and customers.

- How can value-based leader help in enhancing business performance?

Adi Godrej is a true fit as value-based leader. With his strong Zoroastrian-Parsi values and virtues imbibed in him since childhood, he built up and modernized his family business from the era of liberalization in India. Improved processes helped in enhancing the business performance. Basically, value-based leader encourages doing the right thing for the right reasons and not compromising at any cost. He can foster strategic vision and seeks the support and partnership of stakeholders. Valuebased leaders promote transparency and honesty which can be reflected in their communication. They build trust for customers. When leaders value integrity, it means honesty and authenticity, which is important and makes a positive difference in working with others. Choices which are integrity-oriented result in observable and measurable behaviors that build trust with employees, customers, suppliers and shareholders. Collectively, it creates meaningful relationships with diverse stakeholders to drive high performance.

\section{- How do organizations empower the new generation through VBL?}

The values instilled in the fourth generation of Godrej family during their upbringing, has demonstrated characteristics of VBL in their professional stint. In a bold move and a significant leadership change, Adi Godrej’s daughter, Nisaba Godrej will take over the role of managing Director and CEO, Godrej Consumer Products in July 2020. Now comes the harder part. New generation looks for career performance and profit. By fostering empowerment and team work, leaders can gain trust. The next generation wants to focus on purpose and values. Ethics are becoming a core aspect of how job seekers prioritize their job career, and also on how they spend quality time where leaning experiences would be the maximum. Today's generation believes in honesty and transparency. VBL demonstrates words and actions, to realize unity of purpose and to achieve stated goals and objectives. 
$\mathrm{XJM}$

$17,1 / 2$

168

- How to embrace VBL post COVID-19?

Trust is the mother of all values. All relationships are based on mutual trust. Trust is the basic condition for collaboration, cooperation and partnership. During COVID-19, the importance of trust in the corporate world has increased manifold. Care and responsibility for nature and people have become the primary responsibility. Today, there is a re-discovery of direct human relations and communication on the phone or over the digital channels. In post-COVID-19 situation, leaders' roles would be different. Leaders should show gratitude, compassion and empathy toward employees. The most fundamental elements of a value-based leader are authenticity and ethics. This means larders should be transparent and open and can easily connect with people. Leaders must play a crucial role in making people feel psychologically safe. Leaders should empower and involve leaders down the hierarchy in taking crucial decisions for the business.

\section{Appendix 2}

\section{Teaching plan}

Prerequisite conceptual understanding

The students should have a general understanding on:

- ethical theory of leadership;

- authentic leader vs ethical leader;

- value-based leader creating value-based brand; and

- value-based leader in entrepreneurial business.

Additional reading materials can be referred to for a better understanding of the students. The list of relevant reading materials has been added in the references. 


\section{Detailed Flow of Teaching Plan}

\begin{tabular}{|c|c|}
\hline $\begin{array}{c}\text { Section-1 } \\
\text { Godrej Group- Leadership and its Growth }\end{array}$ & $\begin{array}{l}\text { Ideal } \\
\text { Duration } \\
40 \text { Minutes }\end{array}$ \\
\hline \multicolumn{2}{|l|}{$\begin{array}{l}\text { Description } \\
\text { - Genesis of Godrej } \\
\text { - Leadership and its growth }\end{array}$} \\
\hline \multicolumn{2}{|c|}{$\begin{array}{l}\text { Students need to read the case and have a fair knowledge about Godrej and different } \\
\text { leadership styles from the relevant reading materials as stated in the teaching notes. }\end{array}$} \\
\hline \multicolumn{2}{|c|}{$\begin{array}{l}\text { Expected Learning Objective } \\
\text { - To analyze the leadership of Godrej Group over generations starting from its } \\
\text { inception and their achievements }\end{array}$} \\
\hline \multicolumn{2}{|c|}{$\begin{array}{l}\text { Students should be able to draw substantial differences in the leadership styles of the } \\
\text { various stalwarts in the Godrej Group over the years right from its inception. This will } \\
\text { also help the students to appreciate the different business models used by Godrej Group. }\end{array}$} \\
\hline \multicolumn{2}{|l|}{$\begin{array}{l}\text { Forward Linkage } \\
\text { - Adi Godrej's leadership characteristics }\end{array}$} \\
\hline \multicolumn{2}{|c|}{$\begin{array}{l}\text { Foundation day lecture video of XIMB should be played at this stage so as to keep the } \\
\text { students more engaged and engrossed. It will act as a video lecture demonstration. }\end{array}$} \\
\hline \multicolumn{2}{|l|}{$\downarrow$} \\
\hline $\begin{array}{c}\text { Section-2 } \\
\text { Adi Godrej's Leadership Characteristics }\end{array}$ & \begin{tabular}{|l} 
Ideal \\
Duration \\
40 Minutes \\
\end{tabular} \\
\hline \multicolumn{2}{|c|}{$\begin{array}{l}\text { Description } \\
\text { - Different styles of leadership followed by Adi Godrej } \\
\text { - Embracing value-based leadership style, derived from authentic and ethical leadership } \\
\text { style }\end{array}$} \\
\hline \multicolumn{2}{|c|}{$\begin{array}{l}\text { Leadership framework should be discussed here with the help of the diagram as depicted } \\
\text { in the teaching note. }\end{array}$} \\
\hline \multicolumn{2}{|c|}{$\begin{array}{l}\text { Expected Learning Objective } \\
\text { - To analyze the leadership styles of Adi Godrej, who is considered to be the most } \\
\text { successful leader of the Godrej Group from the era of the Indian liberalization } \\
\text { - To analyze and embrace the value-based leadership, which has a positive impact on } \\
\text { volatile, uncertain, complex and unambiguous situation like COVID-19 }\end{array}$} \\
\hline $\begin{array}{l}\text { Students should be able to demonstrate the pros and pos } \\
\text { studies so far. }\end{array}$ & ership styles \\
\hline
\end{tabular}




\section{References and reading materials}

Chopra, S. (2016), "Godrej chairman Adi Godrej shares leadership lessons", available at: www.dnaindia. com/business/report-godrej-chairman-adi-godrej-shares-leadership-lessons-2200530\#: :text=Ad i $\% 20$ Godrej $\% 20$ is $\% 20 \mathrm{a} \% 20$ most,values $\% 20$ like $\% 20$ any $\% 20$ common $\% 20$ man (accessed 29 August 2020).

Datta, A. and Majumdar, S. (2017), "Adi Godrej: an entrepreneur and a gentleman”, available at: www. forbesindia.com/article/leadership-awards-2017/adi-godrej-an-entrepreneur-and-a-gentleman/48 721/1 (accessed on 29 August 2020).

Gaikwad, R. (2019), “Adi Godrej tells students at leadership summit: Accountability, transparency are needed in times of intolerance", available at: https://mumbaimirror.indiatimes.com/news/ business/adi-godrej-tells-students-at-leadership-summit-accountability-transparency-are-neededin-times-of-intolerance/articleshow/70209735.cms (accessed on 29 August 2020).

Gleeson, B. (2017), "How Values-Based leadership transforms organizational cultures", available at: www.forbes.com/sites/brentgleeson/2017/03/10/how-values-based-leadership-transformsorganizational-cultures/\#174efc8c1fbd (accessed on 29 August 2020).

Hegarty, N. and Salvatore, M. (2018), "Components of ethical leadership and their importance in sustaining organizations over the long term", Journal of Values-Based Leadership, Vol. 11 No. 1, Article, p. 7

Shakeel, F., Kruyen, P.M. and Van Thiel, S. (2019), "Ethical leadership as process: a conceptual proposition”, Public Integrity, Vol. 21 No. 6, pp. 613-624, doi: 10.1080/10999922.2019.1606544. 


\begin{abstract}
About the authors
Lopamudra Pattanayak is MBA Human Resource Management from Xavier School of Human Resource Management, Xavier University Bhubaneswar, India. She interned with Tata Steel Ltd on the project titled "Employees' Perception on HR Practices and Policies Including PMS" in the year 2019 for her summer internship project. She has 25 months of work experience as a Test Engineering Analyst in Accenture Solutions Private Limited, India. She did her Bachelor of Technology in Mechanical Engineering from Kalinga Institute of Industrial Technology, Bhubaneswar. She aspires to pursue a PhD in Human Resources (HR) area in the future. She has been associated as an author of a case entitled "The Rise of Byju's," which got published in the prestigious European Case Clearing House in June 2020.

Lalatendu Kesari Jena is an Assistant Professor (HR) in Xavier School of Human Resource Management, Xavier University, Bhubaneswar, India. He has more than 18 years of experience in both academics and corporate HR (with Hindustan Aeronautics Limited, Indian defense public sector undertaking), including 7 years as Faculty Member in HR at ICFAI University, Hyderabad, India and Central University of Orissa, India. He specializes in the areas of human resource planning, performance management, learning and development and talent assessment. His research interest lies in areas such as human resource management and sustainable development goals; self-steering, selforganizing teams and leadership; job crafting; job insecurity; Millennials and work ethics; return on investment in HR programs; sustainable HR through disruptive leadership; attitude and productivity; joy at work; workplace persuasion; employee retention and leadership challenges; abusive supervision; performance in multi-tasking environment; stress and coping; and meaningful engagement; and he has published papers on them in tiered national and international journals. He has completed his $\mathrm{PhD}$ from IIT Kharagpur, India, on the topic "Workplace Spirituality and Human Resource Effectiveness" and is pursuing post-doctoral research on "Employee Retention and Leadership Challenges" at Loyola Leadership School, Universidad Loyola, Seville, Spain. A passionate trainer, Professor L.K. has conducted several corporate training sessions and leadership workshops for organizations across diverse industries. Lalatendu Jena is the corresponding author and can be contacted at: 1kjena@xub.edu.in

Kalpana Sahoo is an Assistant Professor in the area of Organizational Behavior at Xavier School of Human Resource Management, Xavier University, Bhubaneswar, India. She has more than 15 years of teaching experience. She has published several papers in the areas of learned optimism, positive psychology, competency mapping, employee engagement, emotional intelligence and personality in national and international journals. Her teaching interests are in the areas of quality of work life, emotional quotient and spiritual quotient, psychological well-being, personality and leadership.
\end{abstract}

For instructions on how to order reprints of this article, please visit our website: www.emeraldgrouppublishing.com/licensing/reprints.htm Or contact us for further details: permissions@emeraldinsight.com 